\title{
The Demand for Currency: Is the Underground Economy Undermining Monetary Policy?
}

\author{
NORMAN N. BOWSHER
}

\begin{abstract}
C
URRENCY holdings of the public have risen at a brisk pace for many years, reflecting a progressive expansion in the demand for currency.

Since 1960 the currency component of the money stock has risen at an average 7 percent annual rate. It is reasonable that the public, faced with higher prices, would seek to hold more currency. However, currency holdings adjusted for changes in consumer prices have risen at a 2 percent rate since 1960 while real demand deposits have been unchanged on balance. As a result, currency rose from 25 percent of demand deposits in 1960 to 29 percent in 1970 , to 38 percent in 1979 (table 1). In late 1979 the average holdings of currency for a family of five amounted to an astonishing $\$ 2,500$.
\end{abstract}

This greater demand has been readily accommodated since the supply of currency, as provided for in the Federal Reserve Act of 1913, is elastic. In the U.S. monetary system, any depositor can obtain more currency by withdrawing it from deposit balances at commercial banks. Commercial banks that are members of the Federal Reserve System, in turn, obtain currency to restock inventories from their Federal Reserve District Banks by having their reserve accounts (deposits) charged. Other banks obtain cur rency in exchange for deposits at their member correspondent banks.

The persistent increase of currency into circulation has been surprising in view of several developments which discourage its use. Credit cards, for example, have been substituted for cash in an expanding number of transactions, and the number of checking accounts and traveler's checks issued have continued to grow. Moreover, interest rates have moved to higher levels, raising the cost of holding wealth in the form of currency and coin, which does not earn

\begin{tabular}{|c|c|c|c|}
\hline \multicolumn{4}{|c|}{ 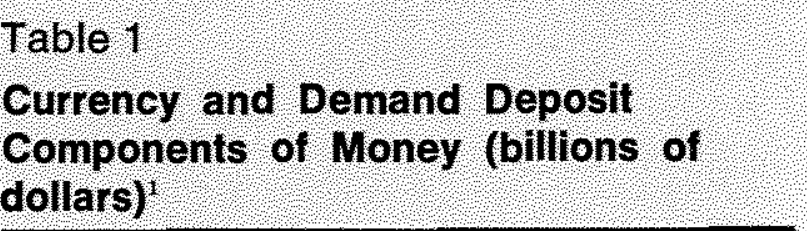 } \\
\hline Year & Currency & oemand & gemando ol \\
\hline 1989 & $\$ 6.4$ & 8296 & 21 \\
\hline 1959 & (4.9.9. & 114.8 & 25 \\
\hline 1960 & 29.0 & 114.5 & 25 \\
\hline 1961 & 29.1 & 1174 & 25 \\
\hline 1962 & 30.1 & 119.6 & 25 \\
\hline 1963 & 31.5 & 1226 & 26 \\
\hline 1964 & 33.5 & 126.8 & 26 \\
\hline 1965 & $35: 3$ & 131.8 & 27 \\
\hline 1966 & 375 & 137.4 & 27 \\
\hline 1967 & 39.4 & 1425 & 28 \\
\hline 1968 & 42.0 & 152.8 & 27 \\
\hline 1969 & 44.8 & 1617 & 28 \\
\hline 1970 & 477 & 166.8 & 29 \\
\hline 1971 & 51.1 & $177 \%$ & 29 \\
\hline 1972 & 54.7 & 1904 & 29 \\
\hline 1973 & 59.3 & 203.9 & 29 \\
\hline 1974 & 649 & 212.8 & 30 \\
\hline 1975 & 710 & 218.9 & 32 \\
\hline 1976 & 778 & 2273 & 34 \\
\hline 1977 & 84,8 & 242.6 & 35 \\
\hline 1978 & 93.2 & 259.6 & 36 \\
\hline 1979 & 102,3 & 268.7 & 38 \\
\hline
\end{tabular}

1 All data are anmual averages of dally frgures except 1939 which a re end of year data. 
interest. In addition, the possession of currency in large amounts is risky; it can be lost, destroyed, or stolen. Holding liquid funds in the form of deposits, on the other hand, has been virtually free of such risks since the advent of deposit insurance.

Because of the sustained growth of currency outstanding relative to demand deposits (chart 1), questions have arisen about what purposes the currency serves. More specifically, does this currency support a huge and growing amount of unreported economic activity? Moreover, since currency is one major use for the monetary base, are there other monetary policy implications of the alleged change in demand for currency? This article explores the answers to these questions.

\section{The Use of Currency in Unrepored Activities}

Suspicion has arisen that the pronounced growth in currency relative to demand deposits reflects an expansion of illegal transactions or other activities that the participants wish to hide. ${ }^{1}$ According to Gutmann, currency lubricates a vast amount of unreported income and employment, an entire subterranean economy whose total product, estimated to be almost $\$ 200$ billion in 1976 , exceeded the nation's entire gross national product in the middle of World War II. ${ }^{2}$

A number of recent developments certainly have provided increased incentives to conduct unreported activities. Inflation has increased markedly the effective income and estate tax rates for most individuals. For example, a family of four who earned $\$ 12,000$ in 1977 and who received an 8 percent increase in income in 1978 owed 21.8 percent more in federal income taxes (using standard deductions). ${ }^{3}$ As inflation pushes individuals into higher effective tax brackets, it provides an incentive to receive income in forms that cannot be traced readily. Currency payments, of course, are less traceable than deposit transfers. Increasing regulations, prohibitions, and reporting burdens provide other incentives for unreported transactions. Similarly, certain illegal activities such as drug

"See "The Undergromen Economy" U.S. News \& World Re" port, October 22, 1979 , pp. 49-52; also, Susan Harrigan, "Blemished Boom - Miami is Prospering, Aided by Latin Money, Illegal Drug Business," Wall Street Joumal, Novenber 28,1979 .

"Peter M. Gutmann, "The Subterranean Economy," Financial Analysts Joumal (November/December 1977), pp. 26, 27, 34. Also see Peter M. Gutmann, "Statistical Illusions, Mistaken Policies," Challenge (November/December 1979), pp. $14-17$.

3See Alfred L. Malabre, Ir., "As Salaries Climb With Prices, People Pay More of Income in Taxes Despite Rate Cuts," Wall Street Jounal, November 28, 1979.

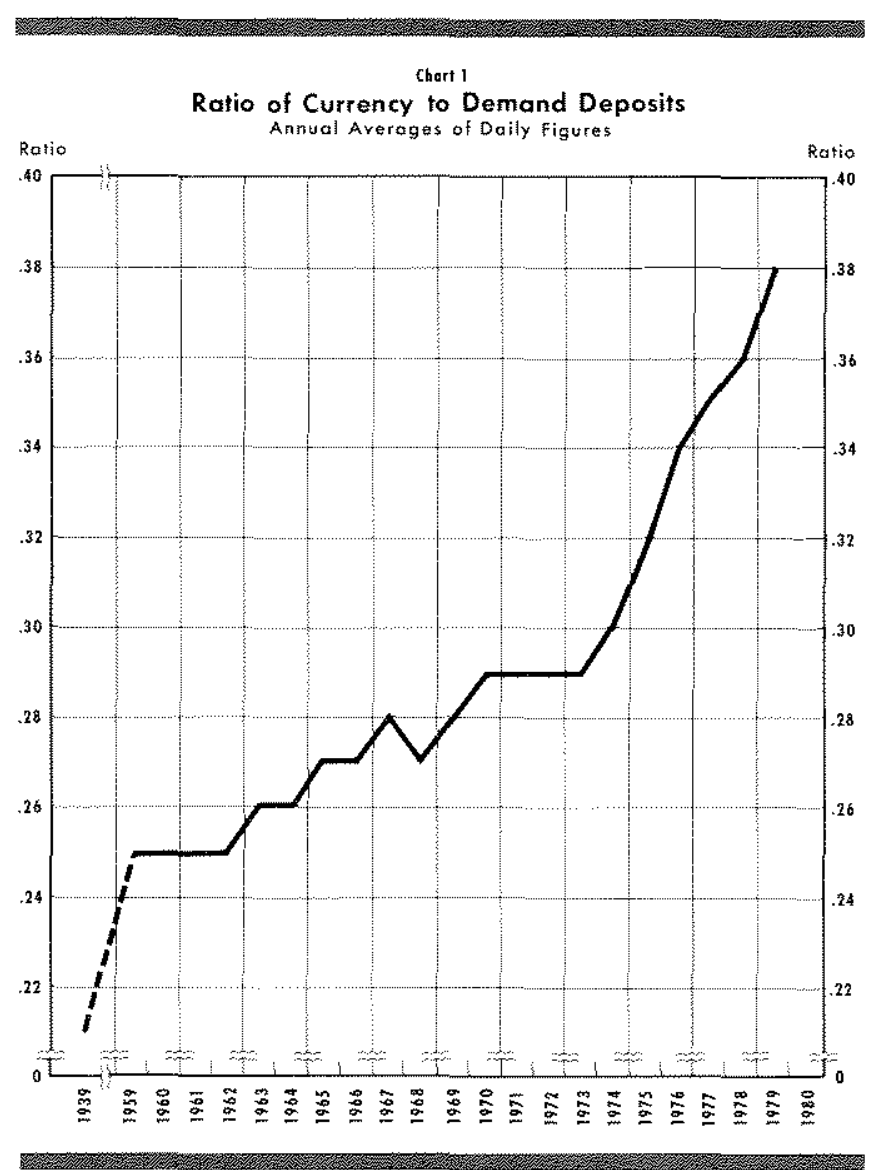

dealing, which are almost always transacted in currency, apparently have expanded.

Nearly everyone receives a minor amount of unreported income in currency from "friendly" bets, personal services, garage sales, etc. Any firm or person who receives currency in a business transaction has the option of joining, at least in part, the subterranean economy of unreported income. Such opportunities exist for many engaged in the professions and those performing repair work and personal services, where it is traditional to compensate individuals with cash payments. Wages for part-time work, especially for child care and domestic workers, also are frequently paid in cash.

Since reliable information on currency usage is unavailable, indirect evidence has been relied on to support conclusions about the dollar volume of unreported transactions. Gutmann's estimates of "underground" activity financed by currency were based on several simple relationships and assumptions. He observed that the ratio of currency to demand deposits had risen markedly. In the five years before World War II, which he selected as a base for comparison, the ratio of currency to demand deposits averaged 
Table 2

\section{Ratio of Currency to Deposits}

\begin{tabular}{|c|c|c|}
\hline Year & $\begin{array}{l}\text { Demand } \\
\text { deposts }\end{array}$ & $\begin{array}{l}\text { Tolal } \\
\text { deposits }\end{array}$ \\
\hline 1939 & 21 & 11 \\
\hline 1959 & 25 & 16 \\
\hline 1969 & 28 & 13 \\
\hline 1976 & 34 & 12 \\
\hline 1979 & 38 & 13 \\
\hline
\end{tabular}

1 All data are armul averages of dally figures ercept 1939 which are end-of-vear data.

21.7 percent. By 1976 this ratio had risen to 34.4 percent. If the ratio of currency to demand deposits required to support legal activities had not changed, the 12.7 percentage-point increase in currency (or $\$ 28.7$ billion) over and above the rise in demand deposits represents funds devoted to increased illegal activity. Furthermore, if each dollar of currency used for illegal transactions supports the same amount of activity as each dollar of money held for legal purposes ( $\$ 275.3$ billion of demand deposits plus legal currency produced $\$ 1,693$ billion of reported GNP in 1976 ), then the $\$ 28.7$ billion held for illegal activities produced an estimated $\$ 176$ billion of unreported income.

This estimate is conservative according to Gutmann. It makes no allowance for unreported income in the pre-World War II base period, it takes for granted that the earlier downward trend in the currency to demand deposit ratio would not have continued into the postwar period, it assumes all demand deposits are held for transactions and none for compensating banks for services rendered, and it ignores the growth in credit card usage and other currency saving devices.

Several more recent studies provide support for the broad Gutmann conclusion that the volume of unrecorded transactions is indeed substantial. The Internal Revenue Service, from comprehensive audits of a sample of tax returns, estimated that unreported income on 1976 individual income tax returns was as much as $\$ 100$ billion from legal sources. It also revealed no taxes were paid on an additional $\$ 25$ billion to $\$ 35$ billion of individual income from three types of criminal activity - narcotics, illegal gambling, and prostitution.* One result of this study is that the

4Estimates of Income Unteported on Individual Income Tax Returns, Publication Number 1104, Internal Revenue Service (September, 1979).
Treasury is seeking to obtain fuller disclosure of sizable currency transactions. ${ }^{5}$

In another study, Feige estimated that unreported transactions in 1976 totaled $\$ 369$ billion (and a fantastic $\$ 704$ billion in 1978$).{ }^{6}$ He calculated the total value of all transactions in the economy by using outstanding stocks of demand deposits and currency and estimating turnover rates for each. The derived total transactions series has been expanding faster than reported income (GNP). Feige used this excess as a measure of the irregular economy of unreported activity. His research into other possible explanations of the faster growth in transactions than reported income - changes in relative prices, relative volume of financial transactions, and the degree of vertical economic integration - concluded that, if anything, his estimates were low.

According to Gutmann, the underground economy for 1976 was about 10 percent of reported gross national product; the Feige estimate was nearly 22 percent. Using Feige's calculations, unreported transactions had jumped to roughly 33 percent of GNP by 1978. From just before World War II until 1976, reported GNP increased at an average 7.8 percent annual rate; were the subterranean economy included, the trend growth rate would have been 8.1 percent according to Gutmann and 8.3 percent according to Feige. Feige's research indicates that from 1976 to 1978 total nominal output, reported and unreported, expanded at a 16.9 percent annual rate, compared with the 11.8 percent rate of reported GNP.

On the other hand, questions have been raised by other analysts concerning the logic of the assumptions used in arriving at such large estimates of the subterranean economy. For example, Gutmann's estimate ultimately depends on the use of demand deposits as the yardstick for judging currency growth. Were the comparison made with total deposits, the results would have been considerably different. ${ }^{7}$ Indeed, currency has changed little relative to total bank deposits since 1939, which suggests that the growth of demand deposits has slowed rather than that the growth of currency has accelerated (table 2). Hence, the subter-

\footnotetext{
5"Treasury Study Seeks ,Stricter Reporting Rules For Large Currency Transactions," American Banker, November 30 , 1979 .

6Edgar L. Feige, "How Big is the Irregular Economy?" Challenge (November/December 1979), pp. 5-13. In the report Feige observed, "I began this investigation suspecting that the irregular economy was smaller than previous estimates had suggested. I am now convinced that the irregular economy is indeed of staggering proportions and growing rapidly."

Thobert D. Laurent, "Currency and the Subterranean Economy," Economic Perspectives, Federal Reserve Bank of Chcago (March/April 1979), pp. 3-6.
} 
ranean economy may not have grown relative to the rest of the economy.

Although time deposits are close substitutes for demand deposits and currency for many purposes, the value of such criticism is uncertain. It seems reasonable to relate currency to demand deposits for transactions analysis since these two are the only monetary assets that can be directly exchanged for goods and services; other deposits must first be converted into currency or demand deposits before they are spent.

In another criticism Laurent suggested that increases in total transfers of demand deposits and currency are more indicative of the trend of economic activity than increases in the outstanding stocks. ${ }^{8}$ Certain available data indicate a much larger increase in the turnover of demand deposits than of currency. Debits to demand deposit accounts at reporting banks increased by more than 30 times over the period 1939 to 1976. In marked contrast, according to Laurent, currency turnover slowed over the same period. Although there is no firm information on currency transactions, a rough measure of velocity was inferred by observing currency redeemed and destroyed. Currency is redeemed and destroyed when the paper notes show signs of wear, presumably a function of its use in transactions. From 1937 to 1941, the average life of the currency destroyed was 3.1 years; in 1976 it was 5.3 years. To some extent, this lengthening was due to the Federal Reserve's policy of extending ctrrency life by screening it less rigorously. But an examination of data for the early 1970s, before such policy changes occurred, also shows an increase in currency life. The combination of the increased deposit turnover and a slowing of currency turnover markedly changes the significance of the relative growths of the currency and demand deposit stocks. The growth in the currency stock, viewed in this light, appears too small to accommodate both the growth in reported transactions and large expansion in unreported activities.

The Feige study, however, concluded that currency turnover had accelerated since the forties and early fifties, not decelerated. ${ }^{9}$ He noted that the quality of paper used in currency was improved dramatically by a melamine-formaldehyde resin additive in 1957 . Tests demonstrated that, after this development, each bill could be used in nearly twice as many transactions before wearing out.

In addition, Laurent suggested that the rapid

8Ibid.

9Feige, "How Big is the Irregular Economy?"

\section{Table 3 \\ Ratio of Currency and Demand Deposits to Gross National Product

\begin{tabular}{|c|c|c|}
\hline Year & Currency & $\begin{array}{l}\text { Demand } \\
\text { deposits }\end{array}$ \\
\hline 1939 & 07 & 33 \\
\hline 1959 & 06 & 24 \\
\hline 1969 & 05 & 17 \\
\hline 1976 & 05 & 13 \\
\hline 1979 & 04 & 11 \\
\hline
\end{tabular} \\ 1All data are annual averages of dally figures except 1939 which are end-of-year data.}

growth in currency outstanding is due, in part, to an increased use of currency as a store of value. ${ }^{10}$ The increase in large denomination bills suggests hoarding. In fact, there is now more money outstanding in $\$ 100$ bills than in any other currency denomination (larger denominations are no longer issued).

On the other hand, some argue that the abundance of large denomination notes may just as well indicate an increased use of currency for illegal activity as for a store of value. Furthermore, the growth of illegal activity itself increases the stock of currency hoarded. Reportedly, the large tax evader or drug dealer frequently accumulates sizable amounts of currency in the larger denominations. These cash balances are maintained, despite high interest rates, to avoid arousing suspicion in converting this currency into other assets. When it becomes profitable to do so, the holder may purchase a legitimate business to "launder" the illegal gains.

From a casual comparison of the growth of currency and the expansion of spending, there does not appear to be a great unexplained rise in currency. In fact, currency outstanding has expanded at a pace slightly less than the increase in total recorded spending on goods and services (see table 3 ). The marked rise in the ratio of currency to demand deposits, giving rise to suspicions of a rapidly expanding underground economy, has reflected sluggish growth in demand deposits. The lack of demand deposit growth can be explained by a proliferation of alternatives for such deposits, including repurchase agreements, NOW accounts, telephone and automatic transfers between savings and demand deposits, and money market mutual funds.

\footnotetext{
10Laurent, "Currency and the Subterranean Economy,"
} 
In another examination of currency developments, Garcia argues that the rapid increase in currency outstanding should have come as no surprise to forecasters of currency demand. ${ }^{11}$ She notes that, since the $1950 \mathrm{~s}$, the amount of currency outstanding has approximated the predictions based on economic models. Using the econometric equations developed by Goldfeld, Garcia found that currency as a function of reported income, interest rates, and lagged currency holdings behaved as anticipated, while demand deposits rose at a surprisingly slower pace. ${ }^{12}$ Hence, she concludes that the subterranean economy operating on currency has not grown spectacularly since the early fifties; more likely it is roughly the same portion of GNP. ${ }^{13}$

Gutmann responded to the Garcia study by pointing out that an equation may do a satisfactory job of forecasting without affording much insight into underlying causes. ${ }^{14}$ He faulted the currency equations for their omission of both a variable proxying the subterranean economy and the implicit yield on demand deposits. In the latter case, he argued that including the yield on the closest currency substitute-demand deposits - would, ceteris paribus, have led to a forecast of smaller currency growth over the period. This is because the implicit yield on demand deposits has risen, or, alternatively, the price of the substitute has fallen. He claimed that the success of the Goldfeld formulation in predicting currency demand, despite the omitted variables, is explained by the fact that (1) both currency and two of the model's explanatory variables (GNP and interest rates) rose rapidly over the period examined and that (2) the previous period's currency was included as an explanatory variable. $^{15}$

${ }^{11 G i l i a n}$ Garcia, "The Currency Ratio and the Subterranean Economy," Financial Analysts Journal (November/Decem. ber 1978), pp, 64-66, 69. Johannes and Rasche also found the currency ratio relatively stable. James M. Johannes and Robert $\mathrm{H}$. Rasche, "Predicting the Money Multiplier," Journal of Monetary Economics (July 1979), pp. 301-25.

12Stephen Goldfeld, "The Demand for Money Revisited," Brookings Papers on Economic Activity (3: 1973), pp. $577-638$.

130ther studies have also concluded that the Gutmann and Feige estimates of the subterranean economy are excessive See Richard D. Porter and Stephan S. Thuman, "The Currency Ratio and The Subterranean Economy: Additional Comments" (Board of Governors of the Federal heserve System, January 26, 1979, processed); and Pichard D. Porter, "Some Notes on Estimating The Underground Economy," (Board of Governors of the Federal Reserve System, August 10, 1979, processed).

"4eter M. Gutmann, "Professor Gutmann Replies," Financial Analysts Jou'nal (November/December 1978), pp. 67-69.

15 Including a lagged dependent variable in an equation is a valid test of the adjustment of actual to desired quantities in a partial adjustment model.
In brief, it is well known that much income goes unreported - this has been true for decades. Without more accurate information on currency exchanges, however, reliable estimates of unreported activities will be elusive. The great stock of currency outstanding and its persistent expansion in the face of higher costs of holding currency and the widespread use of currency substitutes (e.g., credit cards) certainly support suspicions of increasing irregular transactions. Moreover, heavier tax burdens and government regulation seem to have provided powerful incentives for attempting to hide more activities.

On the other hand, currency has not risen as rapidly as total spending. In addition, the velocity of demand deposits has increased markedly in the past several decades, while evidence on currency turnover indicates only a moderate acceleration (or even a deceleration). It is probable, therefore, that unreported transactions associated with currency have not risen as fast as the relative importance of currency outstanding in the money stock might indicate. However, the persistent expansion in currency outstanding at a time of strong incentives to avoid reporting could indicate that unreported activities have been expanding faster than economic activity generally.

\section{Monetary Control}

The rapid increase of currency outstanding in recent years also has implications for economic stability in addition to the unrecorded direct effects on spending, production, and employment. It is possible that flows of currency out of commercial banks could adversely affect the ability of the Federal Reserve System to control the total money stock. A useful framework for analyzing the impact of currency movements on monetary control is provided by the sources and uses of the monetary base or, more specifically, the net monetary liabilities of the Federal Reserve System and the U.S. Treasury.

Sources of the base include the monetary gold stock, Treasury currency outstanding, member bank borrowings from Reserve Banks, and Federal Reserve float (credit extended on checks received but not yet collected). The largest and dominant source of the base, however, is Federal Reserve holdings of government securities. ${ }^{16}$ Fluctuations in the base caused by irregular movements in the other sources can be read-

\footnotetext{
16 Other more minor factors that must be considered in analyzing the net sources of the base include Treasury cash holdings (having a negative impact), foreign deposits at Reserve Banks (having a negative impact), other Federal Reserve assets, other Federal Reserve liabilities, and capital (having a net negative impact).
} 
ily offset as soon as detected (usually within one business day) by System purchases or sales of government securities. Several factors, such as data revisions, changes in member bank borrowing (in response to credit demands and System purchases and sales of securities), and the two-week lagged imposition of reserve requirements (forcing member banks to obtain reserves by borrowing from Reserve Banks if not otherwise made available) can prevent the System from hitting precise base targets within a month or two. Over a period of several months, however, the growth rate of the base can be determined within a narrow range by System purchases and sales. ${ }^{17}$ As studies generally have shown, fluctuations in monetary aggregates over periods of less than three months have seldom had any measurable effect on prices, employment, or incomes. Thus, the Federal Reserve has the ability to adequately control the magnitude and trend of the monetary base by buying or selling securities in the open market. ${ }^{18}$

Analysis of the uses of the base is more complicated than an examination of its sources. Although there are just two uses of the base, currency in circulation and reserves to support member bank deposits, the analysis of money determination must go behind these aggregates. The U.S. monetary system is com " plicated by the existence of both member and nonmember banks, different classes of member banks, different reserve requirements on different types of deposits, and graduated reserve requirements for deposits of different amounts. It is thus necessary to allocate reserves among numerous types of deposits for both those included in the money stock and those not included (such as government and time deposits), as well as to estimate the amount of excess reserves that the banking system will find expedient to hold.

In addition, a chief factor influencing the amount of money the banking system can create, given an increase in the monetary base, is the proportion of currency to demand deposits that the public desires to hold. If the public held a fixed amount of currency, all increases in the supply of monetary base by the Federal Reserve would remain in the banking system as reserves and would be reflected entirely in a multiple change in deposits, the amount depending on reserve requirement ratios for different types of deposits.

\footnotetext{
${ }^{17}$ Albert E. Burger, "Explanation of the Growth of the Money Stock: 1974-Early 1975," this Review (September 1975), pp. 5-10.

${ }^{18}$ See I. Emrnest Tanner, "Lag in Effects of Monetary Policy: A Statistical Investigation," The American Economic Review (December 1969), pp. 794-805.
}

When currency holdings of the public rise rapidly as they have in recent years, however, the total monetary expansion from a given monetary base injection is greatly reduced. This results because an outflow of currency from banks absorbs an equal amount of reserves. With fewer reserves, the deposit-creating potential of the banking system is reduced by some multiple.

Clearly this increased currency demand must be considered in determining how much monetary base must be supplied to achieve a desired increase in the money stock. Fortunately, the System receives prompt data on currency outstanding through frequent reports, and trend movements of currency have been projected fairly accurately by forecasting models. Hence, prompt action to offset any undesired effects of currency movements has been possible.

During the seventies, currency holdings of the public rose rapidly. Unless offset, this acceleration in the public's demand for currency would have caused the growth rate of the money stock to slow or even to decline at times. The trend growth rate of the money stock, however, was more rapid in the seventies than in any other decade since World War II. During the 1970s there were periods in which the growth rate of the money supply slowed long enough to depress the growth of spending. There is no evidence, however, that the slower money growth reflected an increased demand for currency that could not have been offset by net System purchases of securities promptly enough to avoid any material contractive effects on spending.

\section{Concherions}

The almost steady rise in currency in the past decade has fostered a controversy over whether it reflected a tremendous growth in illegal or otherwise unrecorded activities. Although reliable evidence on the extent of the subterranean economy is lacking, it is no secret that numerous unrecorded transactions take place daily. It also is probable that the volume of such transactions has been expanding faster than the volume of recorded transactions. Certainly, greater tax burdens and additional restrictions on legal activities provide incentives for an increase in subrosa pursuits. A number of studies, however, indicate no pronounced acceleration in unreported activities.

Lack of firm knowledge of the volume of unreported transactions does not reduce its economic importance. The implications of a large, growing, but unrecorded sector in our society are numerous and 
affect measurements of economic activity and the economic policies based on these measurements. For example, because much income goes undetected, tax revenues are smaller than they would be otherwise. ${ }^{19}$ Official statistics, which are based on recorded transactions, understate both the true magnitude and growth rates of sales, income, employment, and production. As a result, economic policies are more apt

${ }^{19}$ See Peter M. Gutmann, "Taxes and the Supply of National Output, Financial Analysts Journal (November/December 1979), pp. 64-66. to exacerbate inflation than if all activities were reported.

Unustally rapid growth in currency outstanding, given our monetary system, can potentially contract the total money stock (demand deposits plus currency). Nevertheless, since information on currency movements into and out of banks is current, and since offsetting transactions can be made by the Federal Reserve within a brief period, potentially depressing effects on the economy from this source have been avoided.

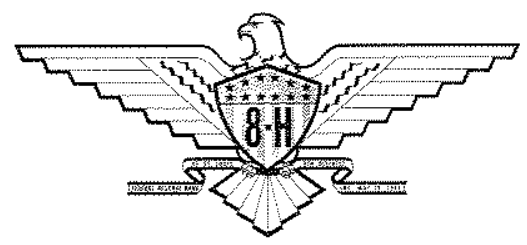

